Volume. 4 Number. 2

Period: July - December 2020; page 54-59

p-ISSN : 2580-1112; e-ISSN : 2655-6669

Jurnal Ilmiah Keperawatan Orthopedi

Copyrighr@2020

(JIKO)

The author owns the copyright of this article

journal homepage: https://ejournal.akperfatmawati.ac.id

DOI : $10.46749 /$ jiko.v4i2.42

\title{
Overview of the Covid-19 Patient Nursing Diagnosis
}

\author{
Nurhidayatun ${ }^{1}$, Abdul Aziz ${ }^{1}$ \\ Fatmawati Central General Hospital, Jakarta - Indonesia \\ Email : ns.nurhidayatun@gmail.com
}

\begin{abstract}
Covid-19 is a pneumonia caused by coronavirus, very fast transmission. This study aims to descriptions nursing diagnosis in covid-19 patients. This is a descriptive study uses quantitative methods. The sampling technique used is consecutive sampling with total samples are 240 medical records of covid-19 patients undergoing treatment at Fatmawati Hospital, both suspected, probable, and confirmed cases. The results showed that nursing diagnoses that often appeared in Covid-19 patients were the risk of infection (spread), ineffective airway, acut pain, anxiety, and the risk of nutritional deficits. The results of this study can be used for the hospital in making Covid-19 Nursing Care Guidelines, and for nurses in increasing their competences in care covid-19 patients.
\end{abstract}

Keywords: Nursing diagnoses, Covid-19

\section{Preliminary}

Coronavirus Disease 2019 (COVID-19) is a contagious disease caused by Severe Acute Respiratory Syndrome Coronavirus 2 (SARSCoV-2). SARS-CoV-2 is a new type of coronavirus that has never been previously identified in humans. There are two types of coronavirus that are known to cause diseases that can cause severe symptoms, such as Middle East Respiratory Syndrome (MERS) and Severe Acute Respiratory Syndrome (SARS) (WHO, 2020).

Common signs and symptoms of COVID-19 infection include acute respiratory symptoms such as fever, cough and shortness of breath. Severe cases of COVID-19 can cause pneumonia, acute respiratory syndrome, kidney failure, and even death (WHO, 2020). On December 31, 2019, the WHO China Country Office reported a case of pneumonia of unknown etiology in Wuhan City, Hubei Province, China. On January 7, 2020, China identified the case as a new type of coronavirus. On January 30, 2020, WHO declared the incident a Public Health Emergency of International Concern (PHEIC) and on March 11, 2020, WHO declared COVID19 a pandemic.

The spread of COVID-19 is fast and widespread because it can be transmitted through human-to-human contact. Until now, news about COVID19 is still the main concern of all countries to be vigilant and stay alert to face COVID-19 for which a cure and vaccine has not been found. The increase in the number of COVID-19 cases is progressing fast enough and there has been a spread between countries.

The increase in the number of cases took place quite rapidly, and spread to various countries in a short time. As of 
27 July 2020, WHO reported 16,262,481 confirmed cases with 648,913 deaths worldwide (Case Fatality Rate / CFR 43.9\%). Indonesia reported its first case on March 2, 2020. Cases are increasing and spreading rapidly throughout Indonesia. As of 27 July 2020 the Ministry of Health reported 98,778 confirmed COVID-19 cases with 4,781 deaths (CFR 4.8\%), while DKI Jakarta Province reported 19,125 confirmed COVID-19 cases with 759 deaths (CFR 3.9\%) (bmgcovid, 2020). As of 1 July 2020, Fatmawati Hospital has treated 595 COVID-19 patients, with 208 deaths (CFR 34.95\%).

Based on research conducted by the Chinese CDC, it is known that the most cases occurred in men (51.4\%) and occurred at the age of 30-79 years and the least occurred at $<10$ years $(1 \%)$. As many as $81 \%$ of cases were mild cases, $14 \%$ were severe, and $5 \%$ were critical (Wu Z and McGoogan JM, 2020).

The incubation period for COVID19 averages 5-6 days, with a range between 1 and 14 days but can reach 14 days. The highest risk of transmission is acquired in the first days of illness due to high concentrations of the virus in secretions. An infected person can be infectious up to 48 hours before symptom onset (presymptomatic) and up to 14 days after symptom onset. A study by Guen et. al, (2020) reported that $12.6 \%$ showed presymptomatic transmission. It is important to know the presymptomatic period because it allows the virus to spread through droplets or contact with contaminated objects. In addition, that there are cases of confirmation asymptomatic (asymptomatic),

The Indonesian government has issued Presidential Decree No.11 of 2020 concerning the Determination of the 2019 Corona Virus Disease (COVID-19) Public Health Emergency. The Decree of the Ministry of Health of the Republic of Indonesia Number HK.01.07 / MENKES
/ 169/2020 concerning the Designation of a Referral Hospital for Certain Emerging Infectious Diseases said that the Fatmawati Central General Hospital is a reference for handling Covid-19 cases in Indonesia, especially the DKI Jakarta area.

From the literature review that has been carried out, there is no evidencebased nursing diagnosis standard for COVID-19 patients, which exists only based on literature studies, so that it makes researchers want to examine nursing diagnoses that occur in COVID19 patients, especially COVID-19 patients. who are being treated at Fatmawati Hospital, so it is hoped that a standard nursing diagnosis for COVID19 patients can be used by all nurses in Indonesia in treating COVID-19 patients. For nurses to establish a nursing diagnosis in these patients.

\section{Methods}

This research is a quantitative research, the research design uses descriptive methods. Researchers collected research data from the medical records of covid patients who had undergone treatment at Fatmawati General Hospital, previously the researchers coordinated with the medical record installation regarding the medical records of Covid-19 patients.

The population in the study were all covid-19 patients treated at Fatmawati General Hospital. The sample selection used consecutive sampling, namely selecting all medical records of covid patients encountered and meeting the inclusion and exclusion criteria. The sample of this study was 240 medical records of covid patients, both suspected, probable, and confirmed cases.

\section{Results and Discussion}

This research was conducted at Fatmawati General Hospital. Data were collected on 11 May - 24 August 2020 with a total sample of 240 medical 
records of covid patients being treated at Fatmawati General Hospital, both suspected, probable, and confirmation diagnoses.

Table 1. Characteristics of Respondents by Age $(n=240)$

\begin{tabular}{lcc}
\hline Age category & Frequency & Percentage \\
\hline Neonates & 25 & $10,41 \%$ \\
Child & 10 & $4,16 \%$ \\
Adult & 155 & $64,59 \%$ \\
Elderly & 50 & $20,84 \%$ \\
\hline Amount & $\mathbf{2 4 0}$ & $\mathbf{1 0 0 \%}$
\end{tabular}

Table 1 shows that the age characteristics of patients range from age levels from neonates to the elderly. This is the same as mentioned by the CDC (2020) that covid can attack various ages. This is in line with the research conducted by Cortis (2020) which looked at the age distribution of patients who experienced covid-19, in the results of his study it was stated that covid occurred in children as much as $16.08 \%$, adults $71.91 \%$ and the elderly 12.01 . \%, in his research it was explained that the elderly is the age most at risk of experiencing Covid-19.

Table 2. Characteristics of Respondents Based on Comorbid Diseases of Covid19 Patients

\begin{tabular}{lcc}
\hline Comorbid & Frequency & Percentage \\
\hline CKD & 39 & $16,30 \%$ \\
Diabetes Mellitus & 34 & $14,20 \%$ \\
Hypertension & 23 & $9,58 \%$ \\
Heart disease & 7 & $2,91 \%$ \\
\hline Amount & 103 & $42,99 \%$ \\
\hline
\end{tabular}

In this study, 103 patients (42.99\%) were covid patients with comorbids. The most common comorbidities were CKD (Chronic Kidney Disease) with 39 patients $(16.30 \%)$, diabetes mellitus as many as 34 patients (14.20\%), hypertension with 23 patients $(9.58 \%)$, and heart disease as many as 7 patients. $(2.91 \%)$, this is in line with what Guan et al (2020) stated that patients who have a history of hypertension, heart disease, diabetes mellitus, stroke, hepatitis B, kidney failure, malignancy or immunodeficiency are at high risk of experiencing covid compared to patients. without a history of the disease.

CKD patients are easily exposed to covid-19, this is because CKD patients experience uremia, vitamin D deficiency, and excessive iron accumulation in the body, thereby increasing the risk of infection. Vitamin D functions to increase phagocytosis, so that in conditions of vitamin D deficiency causes a decrease in phagocytosis, besides that iron that accumulates in the body can stimulate the growth of microorganisms, so CKD patients will easily experience Covid-19 exposure (D'Marco et al., 2020)

Table 3. Characteristics of Respondents Based on The Diagnosis of Covid-19

$$
(n=240)
$$

\begin{tabular}{lcc}
\hline Diagnosis of Covid-19 & Frequency & Percentage \\
\hline Suspect & $\mathbf{8 1}$ & $\mathbf{3 3 , 7 5 \%}$ \\
Neonatus & 25 & $10,41 \%$ \\
Child & 5 & $2,08 \%$ \\
Pregnant mother & 13 & $5,41 \%$ \\
Comorbid & 30 & $12,5 \%$ \\
No comorbid & 8 & $3,33 \%$ \\
Probable & $\mathbf{6 8}$ & $\mathbf{2 8 , 3 3 \%}$ \\
Neonatus & 0 & $0 \%$ \\
Child & 2 & $0,8 \%$ \\
Pregnant mother & 16 & $6,67 \%$ \\
Comorbid & 42 & $17,5 \%$ \\
No comorbid & 8 & $3,33 \%$ \\
Confirmation & $\mathbf{9 1}$ & $\mathbf{3 7 , 9 1 \%}$ \\
Neonatus & 0 & $0 \%$ \\
Child & 3 & $1,25 \%$ \\
Pregnant mother & 5 & $2,08 \%$ \\
Comorbid & 36 & $15 \%$ \\
No comorbid & 47 & $19,58 \%$ \\
\hline Amount & 240 & $100 \%$ \\
\hline
\end{tabular}

Table 5 above shows that the most suspected cases were in patients with comorbids, namely 30 patients $(12.5 \%)$, and the least were suspected cases in pediatric patients, namely only 5 patients $(2.08 \%)$. Most probable cases were in comorbid patients as many as 42 patients $(17.5 \%)$, and no neonates with probable and confirmed cases were found. 
Meanwhile, most confirmed cases were non-comorbid patients as many as 47 patients $(19.58 \%)$, and there were no neonates with confirmed covid-19.

The results of this study also show that in neonatal patients treated at Fatmawati General Hospital, $100 \%$ of the diagnosis of covid is suspected, this is as stated by the CDC (2020) that covid is transmitted through droplet or aerosol transmission not through the placental blood flow of the mother to the fetus, even though the mother confirmed covid19.

In addition, the most comorbid patients were diagnosed as probable, namely 42 patients (17.5\%), this could be because comorbid patients often appear symptoms that are almost similar to Covid, so these patients are treated in the Covid-19 service room. Most confirmed cases occurred in non-comorbid patients as many as 47 patients (19.58\%), this could be due to the length of the covid pandemic that occurred in Indonesia so that more people experienced confirmed covid.

The results of this study also showed that the main complaints of Covid-19 patients were cough $76.7 \%$, fever $72.6 \%$, shortness of breath $48 \%$, sore throat $22 \%$, nausea $20.5 \%$, dizziness $20.5 \%$, dysgeusia $17, \quad 8 \%, 16.4 \%$ anosmia, $16.4 \%$ weakness, $16.4 \%$ whole body pain, $13.7 \%$ decreased appetite, $11 \%$ vomiting, $8.2 \%$ diarrhea, and $9.5 \%$ colds.

This is the same as stated by Heltzer (2020) that the symptoms of Covid patients are fever $78 \%$, cough $57 \%$, fatigue $31 \%$, anosmia $25 \%$, dysgeusia $23 \%$. Likewise, according to Kevin et al (2020) that the signs of Covid symptoms are $88 \%$ fever, $38 \%$ fatigue, $14 \%$ headache, $6 \%$ colds, $19 \%$ shortness of breath, 33\% cough, 4-14\% diarrhea, $15 \%$ muscle pain. Shortness of breath or a frequency of breath $>30 \mathrm{x} /$ minute is a sign of severe pneumonia. In pediatric patients, the increase in respiratory rate was assessed by age.

In Covid-19 patients, anosmia and dysgeusia are often found, this is because Covid-19 patients experience decreased blood oxygenation, including in peripheral blood vessels in the nose and in the mouth, thus affecting the function of these organs (Gonzalez-Duarte \& Kaufmann, 2020).

In covid patients with comorbid symptoms, there was a decrease in consciousness by $12.1 \%$. This is because in the case of covid with comorbids, the patient's clinical symptoms worsen because of the comorbids, so that covid19 patients with comorbids experience a decrease in consciousness due to lack of oxygen in their bodies, especially their brains.

This is as explained by GonzalesDuarte (2020) that covid patients experience hypoxemia due to inadequate gas exchange in the lungs, besides that the replication of the covid virus in the blood can suppress oxygen levels in the blood and eventually oxygen levels in the tissues decrease, so that patients experience loss of consciousness.

Changes in consciousness generally indicate decreased perfusion in the brain so that it requires immediate treatment. In addition, pediatric patients with decreased consciousness, breastfeeding problems, and seizures accompanied by respiratory symptoms can be classified as pneumonia / severe Acute Respiratory Infections (ARI).

Table 4. Nursing Diagnosis of Covid-19 Patients at Fatmawati Hospital

\begin{tabular}{lcc}
\hline \multicolumn{1}{c}{ Nursing Diagnosis } & Frequency & Percentage \\
\hline Risk of infection & 149 & $62,08 \%$ \\
Ineffective breathing pattern & 89 & $37,08 \%$ \\
Acute pain & 62 & $25,83 \%$ \\
Anxious & 57 & $23,75 \%$ \\
Risk of nutritional deficits & 52 & $21,66 \%$ \\
Airway clearance is not & 50 & $20,83 \%$ \\
effective & & \\
Risk of falling & 48 & $20,00 \%$ \\
Risk of hypovolemia & 44 & $18,33 \%$ \\
Activity intolerance & 29 & $12,08 \%$
\end{tabular}




\begin{tabular}{lcc}
\hline \multicolumn{1}{c}{ Nursing Diagnosis } & Frequency & Percentage \\
\hline Hyperthermia & 19 & $7,91 \%$ \\
Excess fluid volume & 12 & $5,00 \%$ \\
Decreased cardiac output & $\mathbf{1 1}$ & $4,58 \%$ \\
Risk of ineffective cerebral & 11 & $4,58 \%$ \\
perfusion & & \\
Self-care deficit & 11 & $4,58 \%$ \\
Risk of impaired skin & 11 & $4,58 \%$ \\
integrity & & \\
Risk of injury to the fetus & 8 & $3,33 \%$ \\
Gas exchange disorders & 7 & $2,91 \%$ \\
Risk of bleeding & 2 & $0,83 \%$ \\
\hline
\end{tabular}

The most important nursing diagnosis in covid patients is the risk of infection, this is because the transmission of the Covid-19 virus is very fast, so the risk of spreading the infection can occur. As explained by WHO (2020) that the Covid virus can quickly spread through droplets or droplets of saliva and air, because the virus particles are very small.

In addition to the risk of infection, the nursing diagnosis that appears in covid patients is ineffective breathing patterns, ineffective airway clearance, gas exchange disorders, cerebral tissue perfusion disorders, and renal tissue perfusion disorders, activity intolerance, this is related to the supply and demand for oxygen in the body., if the body lacks oxygen it causes disturbances in the respiratory system and other organs, both the kidneys and the cerebral.

Nursing diagnoses that arise include ineffective breathing patterns, ineffective airway clearance, activity intolerance, decreased cardiac output, risk of ineffective cerebral perfusion, nursing diagnoses that appear related to decreased oxygenation in covid patients (D'Marco et al, 2020).

In pregnant women, a nursing diagnosis is also obtained, the risk of injury to the fetus and the risk of bleeding, this is also related to the risk of decreased oxygenation from mother to fetus due to the mother experiencing covid infection (Yang, 2020), so the fetus is at risk of experiencing physical harm or damage during the pregnancy (PPNI, 2017)
In addition to physical nursing diagnoses, there were also nursing diagnoses of anxiety in covid patients. This is related to the Covid-19 pandemic which is a new source of stress for the world community today. The fear of covid-19 creates serious emotional distress, covid-19 patients must undergo strict isolation and must keep their distance from other people, including their immediate family, coupled with the presence of stigma and discrimination against people with covid-19 who are considered very contagious (Winurini, 2020). This results in covid patients feeling restless, having trouble sleeping, feeling worried about their covid condition, complaining of dizziness, all of which are symptomatic signs of patients experiencing anxiety (PPNI, 2017).

\section{Conclusion}

Nursing diagnosis in covid-19 patients is very dependent on the response that occurs from covid-19 patients, ranging from mild to severe. Nursing diagnosis in covid-19 patients is related to patient oxygenation problems due to ventilation, diffusion and perfusion. In addition, nursing diagnoses in covid-19 patients are not only related to physical problems, but also to the patient's psychology.

Nurses can improve their competence in assessing clinical covid patients, so that the nursing diagnosis is enforced according to the patient's condition. This description of nursing diagnoses in covid patients can be used as material or reference in making guidance for covid-19 patient nursing care.

\section{Thank-you note}

Fatmawati Hospital, the Board of Directors, especially the Director of Human Resources for Education and Research, the Research Division, the Nursing Committee, the Medical Record 
Installation which has provided the opportunity for researchers to conduct this research.

\section{Bibliography}

1. Cortis, Dominic., (2020). On Determining the Age Distribution of Covid-19 Pandemic. Frontiers in Public Health.

2. Direktorat Jenderal Pencegahan dan Pengendalian Penyakit. (2020). Pendoman Pencegahan dan Pengendalian Coronavirus Disease (COVID-19).ed.4. Jakarta: Kementerian Kesehatan .RI.

3. D'Marco et al (2020). Coronavirus disease 2019 in chronic kidney disease. Clinical Kidney Journal.

4. Guan et al (2020). Comorbidity and its impact on 1,590 patients with COVID-19 in China: A Nationwide Analysis. Cold spring Harbor Laboratory.

5. Gonzales-Duarte, A., \& Kaufmann, Lucy Norcliffe., (2020). Is Happy hypoxia in Covid-19 a disorder of autonomic interoceptions? A hypothesis. Clinical Autonomic Research.

6. Heltzer, L., (2020). Nursing Management of Covid. https://everynurse.org/blog/nursingmanagement-covid-19/

7. Kelvin et al., (2020). COVID-19 and Cardiovascular Disease. Journal circulation.

8. Perhimpunan Dokter Paru Indonesia.(2020). Panduan Praktik Klinik (PPK). Jakarta: Pengurus Pusat PDPI.

9. Persatuan Perawat Nasional Indonesia / PPNI (2017), Buku Standar Diagnosis Keperawatan Indonesia : Definisi dan Indicator Diagnostik, edisi 1, cetakan 3. Jakarta : DPP PPNI.

10. Persatuan Perawat Nasional Indonesia / PPNI (2017). Standar Luaran Keperawatan Indonesia, edisi 1, cetakan 2. Jakarta : DPP PPNI.
11. Persatuan Perawat Nasional Indonesia / PPNI (2018), Buku Standar Intervensi Keperawatan Indonesia : Definisi dan Tindakan Keperawatan, edisi 1, cetakan 2. Jakarta : DPP PPNI.

12. Yang, H., Wang, C., \& Poon, L.C., (2020). Novel Coronavirus Infection \& Pregnancy. Wiley Online Library.

13. https://www.kemkes.go.id/resources/ download/info-terkini/COVID19/FAQ\%20coronavirus\%20disease$\% 20 \mathrm{COVID}-$ 19\%20Kementerian\%20Kesehatan\% 202020.pdf/diunduh 27 Maret 2020

14. https://www.who.int/docs/defaultsource/coronaviruse/situationreports/20200313-sitrep-53-covid19.pdf?sfvrsn=adb3f72_2//diunduh 27 Maret 2020

15. www.cdc.gov 